\title{
Molecular characterization of ESBL gene in Citrobacter spp. and antibacterial activity of omega-3 against resistant isolates
}

\author{
Mayyada F. DaRWEesh
}

Biology Department, Faculty of Science, Kufa University, Najaf, Iraq.

\section{ARTICLE INFO \\ Received 11 July 2017 \\ Accepted 08 September 2017}

\section{Keywords:}

Citrobacter spp.,

ESBL-genes,

omega-3 antibacterial activity.

\begin{abstract}
The study aimed to investigate the prevalence and resistance pattern of different Citrobacter spp., phenotypically and genotypically, to $\beta$-lactam antibiotics, then to evaluate the antibacterial activity of omega- 3 extracted from flaxseed against isolates that harboring resistance genes. Herein, 19 Citrobacter isolates were isolated from 100 stool and urine samples taken from patients attended to AL-Sadar Hospital during JuneDecember 2016. Clinical samples were then cultured on specific media, thereafter, isolates were identified depending on morphological, biochemical characteristics and VITK-2. The results showed that the Citrobacter spp. comprise 19/78 (24\%) of positive bacterial growth on macConky agar, from which $14.1 \%$ were C. freundii, C. koseri represented $6.1 \%$ and C. farmeri were $3.8 \%$ of the total. The results of antibiotic susceptibility showed that all Citrobacter $100 \%$ isolates were resistant to ampicillin and cefoxitin, but were sensitive to imipinim. Moreover, the isolates initally showed different degrees of resistant to $\beta$-lactam antibiotics. Furthermore, by confirmatory test, the results observed that $17 / 19(89.4 \%)$ of the isolated were extended-spectrum $\beta$-lactamase (ESBL - producers). Finally, using the PCR technique to detect $b l a_{\text {Genes }}$, the results revealed that $14 / 17$ (82.3) of potential ESBL producing Citrobacter harbored one or more ESBL genes. These included 10 isolates of C. freundii and 4 isolates of C. koseri. In related work, extracts of essential fatty acid semicarbazide - omega3 (EFASC) from Linum usitatissium (Flaxseed) were tested to evaluate their activity against resistant isolates. The results demonstrate the broad spectrum antibacterial property of EFASC compounds against resistant bacteria. In conclusion, this study found increase prevalence of multi-drug resistance MDR Citrobacter spp. as causative agents in clinical cases. Considering the antibacterial activity of EFASC that displayed high activity against resistant pathogens, deservedly, attention must be paid to developing their use as alternative antibiotics.
\end{abstract}

\section{INTRODUCTION}

Citrobacter is a gram-negative rod motile bacteria, a Enterobacteriaceae. Its name is derived from its ability to use citrate as a sole carbon source [1]. Infections with Citrobacter spp. have seen increasing importance as a cause of serious nosocomial outbreaks that are difficult to treat using most common antibiotics [2,3]. Indeed, locally, several studies refer to the prevalence levels of Citrobacter infections $[4,5,6]$.

Extended-Spectrum $\beta$-Lactamase (ESBL), a member of the $\beta$-lactamases enzymes family that hydrolyzes the $\beta$-lactams ring, leads to loss of bactericidal activity of a wide variety of antibiotics, including third generation

\footnotetext{
* Corresponding author

e-mail: mayadajalala@yahoo.com
}

cephalosporins and penicillins [7]. The increase prevalence of ESBL producing gram- negative bacteria is a significant problem in treating bacterial infection, in addition to the different induced side effects such as allergy to some antibiotics, nephrotoxicity, ototoxicity and alteration of normal gut flora. For this reason, seeking new alternative medicines which control pathogens while showing reduced side effects has become a crucial part of drug development research. Yet even now, 'green' medicine has been used for the medication of different bacterial disease [8].

Seeds from Linum usitatissium (Flaxseed), which contain about 36 to $40 \%$ of oil, are a rich source of the following unsaturated essential fatty acids (USFA): Omega 3 (linolenic acid), Omega 6 (linoleic acid) and oleic acid content [9]. Linolenic acid and other compound of essential fatty 
acids (EFAs) have been assessed as possible new agents for treating skin infections caused by $P$. acnes and $S$. aureus [10]. Of note, several studies have confirmed the successful use of USFA against $S$. aureus, Pseudomonas spp. and $L$. monocytogenes [11]. The semicarbazides found in the EFAs are the raw material of the semicarbazones that possess a wide spectrum of antibacterial activities [12].

\section{MATERIALS AND METHODS}

\section{Bacterial Characterization}

A total of 100 stool and urine specimens were collected under aseptic conditions from patients attending to Al-Sadar Medical City in AL-Najaf province. These were inoculated on MacConkey agar and XLD agar (Oxoid Cambridge, UK) and incubated at $37^{\circ} \mathrm{C}$ for $24 \mathrm{~h}$. The morphological characteristics of the colonies including size, shape and color, were recorded, the suspected Citrobacter were made relevant by biochemical test [13], then finally confirmed by using a Vitek-2 Compact (Bio Mérieux, France).

Antibiogram test. Antibiotic susceptibility was carried out on all isolates using the Kirby Bauer disc diffusion method. The results were inter-operated by measuring the zone of inhibition in $\mathrm{mm}$. Subsequently, using the results of testing with cefotaxime, ceftazidime, ceftriaxone, and aztreonam (30 $\mu \mathrm{g}$ of each), $\beta$-lactam resistant isolates (ESBL Production) were initially screened out according to [14]. Their presence were then confirmed by the disk approximation test according to [15]. Herein, any augmentation which appear to increase the diameter of the inhibition zone between the central amoxi-clav disk and any of the surrounding disks for the cefotaxime, ceftazidime, ceftriaxone, and aztreonam that was distributed around the amoxi-clav disk was considered as positive for the presence of ESBL Production. Disks that showing resistance or intermediate susceptibility were recorded.

Genomic DNA extraction. The cell pellets from all resistant isolates were used for extracting genomic DNA by way of the Genomic DNA Mini extraction kit (Geneaid, USA), following the manufacturer's instructions. The extracted DNA was kept in sterile eppendorf tubes and stored at $-20^{\circ} \mathrm{C}$ prior to PCR.

Detection of resistance genes. PCR amplification for detecting the four $b l a_{\text {Genes }}, b l a_{\mathrm{CTX}-\mathrm{M}}, b l a_{\mathrm{TEM}}, b l a_{\mathrm{SHV}}$ and $b l a_{\mathrm{OXA}}$ was carried out according to Bioneer corporation, Korea practice, as shown in Table 1.

Table 1. The sequences of synthesized oligonucleatoide

\begin{tabular}{|c|c|c|c|c|}
\hline $\begin{array}{c}\text { Primer } \\
\text { name }\end{array}$ & & $\begin{array}{l}\text { Sequences } \\
(5-3)\end{array}$ & $\begin{array}{l}\text { Molecular weight } \\
\text { of amplicon (bp) }\end{array}$ & Ref. \\
\hline \multirow{2}{*}{ CTX-M } & $\mathrm{F}$ & CGCTGTTGTTAGGAAGTGTG & \multirow{2}{*}{754} & \multirow{2}{*}{16} \\
\hline & $\mathrm{R}$ & GGCTGGGTGAAGTAAGTGAC & & \\
\hline \multirow{2}{*}{ SHV } & $\mathrm{F}$ & AGGATTGACTGCCTTITTG & \multirow{2}{*}{392} & \multirow{2}{*}{17} \\
\hline & $\mathrm{R}$ & АTTTGCTGATTTCGCTCG & & \\
\hline \multirow{2}{*}{ OXA } & $\mathrm{F}$ & ATATCTCTACTGTTGCATCTCC & \multirow{2}{*}{619} & \multirow{2}{*}{18} \\
\hline & $\mathrm{R}$ & AAACCCTTCAAACCATCC & & \\
\hline \multirow{2}{*}{ TEM } & c & ATCAGCAATAAACCAGC & \multirow{2}{*}{516} & \multirow{2}{*}{18} \\
\hline & $\mathrm{H}$ & CCCCGAAGAACGTTTC & & \\
\hline
\end{tabular}

PCR mixtures $(25 \mu \mathrm{L})$ containing $5 \mu \mathrm{L}$ of DNA template, $12.5 \mu \mathrm{L}$ master mix (Promega,USA) and $1.25 \mu \mathrm{L}$ of each primer and $5 \mu \mathrm{L}$ of sterilized distilled water were used. PCR amplifications were performed in an Agilent, USA Thermo Cycler according to manufacturer's procedures $[16,17,18]$. PCR products were then electrophoresized on $1.5 \%$ agarose gels, stained with ethidium bromide (Biobasic, Canada), visualized by UV illumination and were photographed by a Cleaver gel documentation system (Biometer/Germany).

Plant collection. Flaxseed were obtained from the local market in Al-Najaf City. The seeds were cleaned and the foreign materials were removed. The dried seeds were then powdered, and stored in a refrigerator at $4{ }^{\circ} \mathrm{C}$ to await further processing [19].

Preparation of oil. The flaxseed oil was extracted using hexan solvent (1: $4 \mathrm{w}$ : v) in a Soxhlet apparatus (Preciso, England) for $24 \mathrm{~h}$. Then, EFA was isolated from the oil using a Cleavenger (Shepreth, England), according to [19]. Purity and identification of EFA-omega3 compounds by TLC was carried out according to [20].

Preparation of EFA - Semicarbazide (EFASC). One gram of EFA-omega-3 were dissolved in $4 \mathrm{ml}$ of methanol and $1: 1 \mathrm{H}_{2} \mathrm{SO}_{4}$, then $4 \mathrm{mg}$ of thiosemicarbazide in methanol were added to this solution with constant stirring at room temperature for $4 \mathrm{~h}$. Following this, $\mathrm{NH}_{4} \mathrm{OH}$ was added till alkaline, then stirred for about $15 \mathrm{~min}$ and kept overnight. The resulting crystals was filtered, dried and recrystallized [21]. A stock solution was prepared by dissolving $500 \mathrm{mg}$ of dried extracts with $1 \mathrm{ml}$ DMSO to give a final concentration of $500 \mathrm{mg} / \mathrm{ml}$, from which a serial concentration was prepared [19]. The agar well diffusion method was then applied to determine the EFASC antibacterial activity, according to [22].

\section{Statistical analysis}

Analysis of data was performed by using Statistical Package for Social Science (SPSS) system/ version 17 and Microsoft Office Excel 2007. Results were expressed as mean \pm S.D. P-value was considered significant when it is less than 0.05. The analysis of variance (ANOVA) was also applied.

\section{RESULTS}

\section{Identification of Citrobacter}

Citrobacter spp. gram negative colonies appear small, pink and convex on MacConkey agar, and yellow, smooth, flat and round on XLD agar. All the 19 isolates of Citrobacter spp. were lactose fermenting, motile and gave positive test results for catalase, methyl-red and citrate, and negative results for Indole (except $C$. koseri), oxidase and VogesProskuaer. These also have the ability to ferment glucose on Kligler iron agar (A/A). The results demonstrate an ID message confidence level that is considered excellent by way of the VITEK-2 compact system.

Nineteen bacterial isolates were identified as Citrobacter spp. from the 78 positive bacterial growths seen on MacConkey agar and recovered from the 100 clinical specimens collected. This result showed a frequency $24 \%$. The isolates were represented by $11(14.1 \%)$ isolates of $C$. freuendii, and 5 
(6.41\%) C. koseri, while 3 isolates (3.8\%) were identified as C. farmeri (Figure 1), and 59 isolates (75.65\%) showed growth of other gram negative bacteria which included Klebsiella spp., E.coli, Pseudomonas spp. and Proteus spp. (Figure 1):

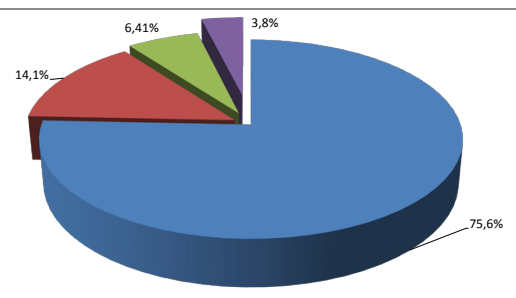

mother $S p=C$. freunii $\equiv C$. koseri $=C$. formeri

Figure 1. Pie chart showing the distribution of Citrobacter spp.

\section{Antibiogram test}

The results of the antibiogram tests for all Citrobacter spp. to 11 antibiotics were summarized in (Figure 2). This revealed that all isolates were multi-drug resistant and all were $100 \%$ resistant to ampicillin and cefoxitin, while $100 \%$ sensitive to imipenem antibiotic. Among the third-generation cephalosporins tested, $C$. freundii appear highly resistant against amoxi-clav and cefotaxime (90.1\% of all isolates), while resistance to ceftazidime and cefriaxon was recorded in $81.8 \%$ of all isolates, and various levels of resistance were observed towards oxacillin (72.7\%), ciprofloxacin (54.5\%) and gentamycin (63.6\%). The resistance pattern of C. koseri and $C$. farmeri are shown in (Figure 2).

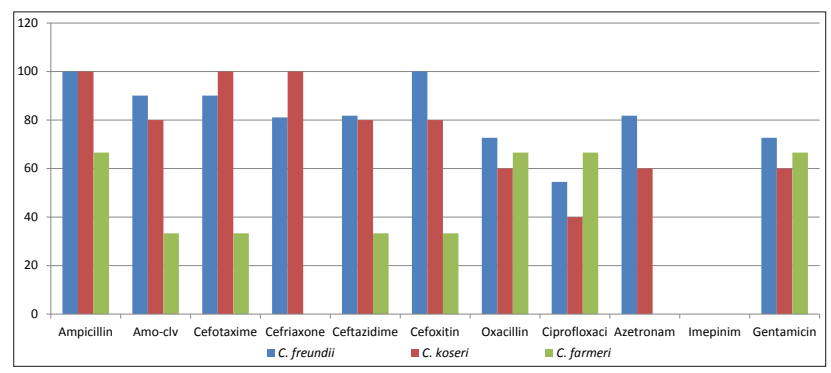

Figure 2. Antibiotic resistance pattern of Citrobacter spp.

\section{Correlation in antibiotic resistance between phenotypic (initial, confirmatory) and genotypic}

As shown in Table 2, the results of initially and confirmatory testing revealed that all Citrobacter isolates were considered potential ESBL-producers initially, while the confirmed results showed that only $17 / 19(89.4 \%)$ of the isolates were actual ESBL producers. The results of detecting for $b l a_{\mathrm{Genes}}\left(b l a_{\mathrm{CTX}-\mathrm{M},}, b l a_{\mathrm{TEM}}, b l a_{\mathrm{SHV}}\right.$ and $\left.b l a_{\mathrm{OXA}}\right)$ via PCR revealed that $14 / 17$ of all potential ESBL producing Citrobacter carried at least one of the ESBL genes. These included 10 isolates of $C$. freundii and 4 isolates of $C$. koseri.

The results also revealed that 12 isolates contained only one ESBL gene type. These are: $5 b l a_{\mathrm{CTX}-\mathrm{M}}, 3 b l a_{\mathrm{TEM}}, 2 b l a_{\mathrm{SHV}}$ and $2 b l a_{\text {OXA }}$. Moreover, 2 isolates of $C$. freundii had the combination of two genes: one of blaSHV genes in combination with $b l a_{\text {CTX-M }}$ genes, and one of $b l a_{\text {TEM }}$ genes in combination with $b l a_{\text {СТХ-M }}$ genes (Table 2, Figure 3).
Table 2. The correlation of phenotypic, genotypic to antibiotic resistance in Citrobacter spp.

\begin{tabular}{|c|c|c|c|c|c|c|}
\hline \multirow{2}{*}{$\begin{array}{c}\text { Name \& No.of } \\
\text { isolate }\end{array}$} & \multicolumn{2}{|c|}{ Phenotypic } & \multicolumn{4}{|c|}{ Genotypic } \\
\hline & Initial & Confirmatory & CTX-M & TEM & SHV & OXA \\
\hline C. freundii 1 & + & + & - & + & - & - \\
\hline C. freundii 2 & + & + & - & \pm & - & - \\
\hline C. freundii 3 & + & + & \pm & - & \pm & - \\
\hline C. freundii 4 & + & + & \pm & + & - & - \\
\hline C. freundii 5 & + & + & \pm & - & - & - \\
\hline C. freundii 6 & + & + & - & - & - & \pm \\
\hline C. freundii 7 & + & + & - & - & - & \pm \\
\hline C. freundii 8 & + & + & - & - & \pm & - \\
\hline C. freundii 9 & + & + & + & - & - & - \\
\hline C. freundii 10 & + & + & \pm & - & - & - \\
\hline C. freundii 11 & + & + & - & - & - & - \\
\hline C. koseri 1 & + & + & - & - & \pm & - \\
\hline C. koseri 2 & + & + & - & \pm & - & - \\
\hline C. koseri 3 & + & + & \pm & - & - & - \\
\hline C. koseri 4 & + & + & \pm & - & - & - \\
\hline C. koseri 5 & + & + & - & - & - & - \\
\hline C. farmeri 1 & + & + & - & - & - & - \\
\hline C. farmeri 2 & + & - & - & - & - & - \\
\hline C. farmeri 3 & + & - & - & - & - & - \\
\hline Total & 19 & 17 & 7 & 4 & 3 & 2 \\
\hline
\end{tabular}

\section{Frequency of ESBL genes in Citrobacter spp.}

The results of ESBL-gene distribution detection has revealed that CTX-M $\beta$-lactamase was the most prevalent $(43.7 \%)$ among the ESBL producing isolates; followed by TEM - $\beta$-lactamase (25\%) and SHV $\beta$-lactamases $(18.75 \%)$, while OXA $\beta$-lactamase gave $12.5 \%$ (Figure 3, $4 \mathrm{~A}, \mathrm{~B}, \mathrm{C}, \mathrm{D}$ ):

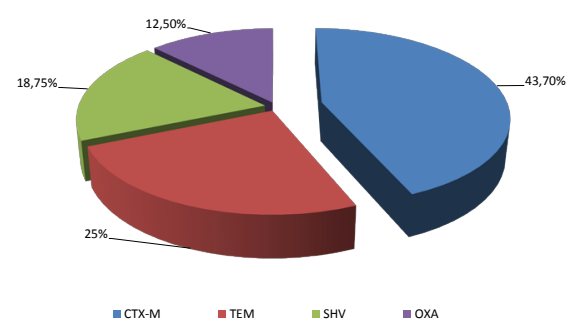

Figure 3. ESBL gene distribution Citrobacter spp.

\section{Thin Layer Chromatography}

The analysis of the TLC chromatography of EFASC omega 3 as shown in (Table 3 ) has revealed the presence of light brown spots in day-light and light green spots by using UV light after iodine spray. Such spots have $\mathrm{R} f$ equal to 0.37 , similar to the standard (EFASC-Omega3) which has $\mathrm{R} f$ value 0.37 , and which appear dark brown in day-light and dark green under UV-light.

Table 3. Thin Layer Chromatography Essential Fatty Acid Semicarbazide of flaxseed (oil) compounds

\begin{tabular}{|c|c|c|}
\hline Properties & EFA (Omega 3) & EFASC \\
\hline $\mathrm{Rf}$ & 0.37 & 0.37 \\
\hline Color by day-light & Dark Brown & Light Brown \\
\hline Color under UV-Light & Dark Green & Light Green \\
\hline
\end{tabular}



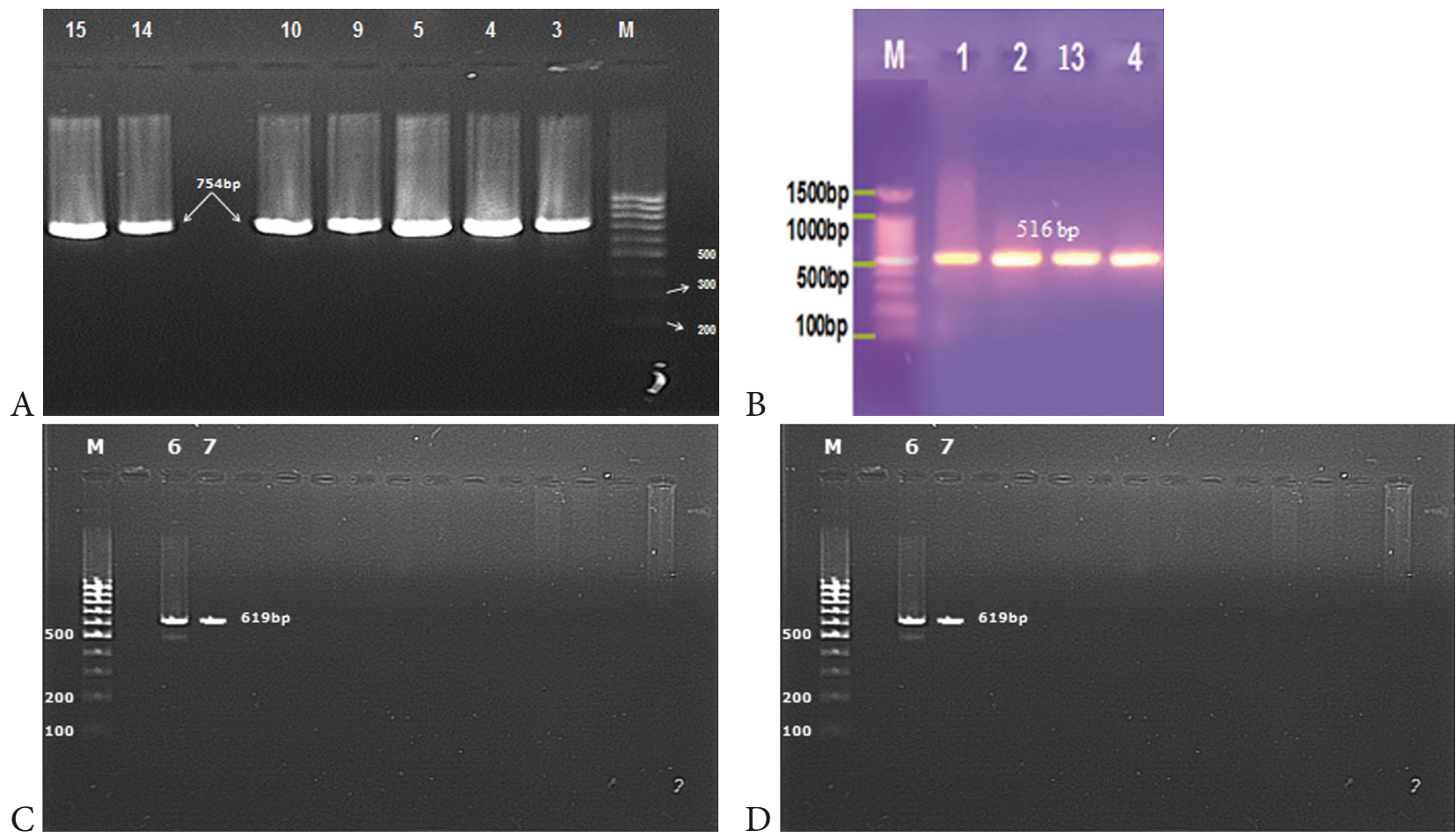

Figure 4. Ethidium bromide stained agarose gel (1.5\% agrose gel, $75 \mathrm{~V}, 1.25$ hours) showing PCR amplification products with (A) CTX-M gene. Lane L: Ladder (100 - 1517bp). Lane (3,4,5,9,10) C. f. No. 3,4,5,9,10, respectively. Lane (14,15) C. koseri No. 3,4. (B) TEM gene. Lane $(1,2,4)$ C. f. No. 1,2,4. Lane (13) C. koseri No. 2. (C) OXA gene. Lane (6,7) C. f. No. 6,7 (D) SHV gene. Lane (3,8) C. f. No. 3,8 , respectively. Lane (12) C. koseri No. 1

\section{Evaluation of the antibacterial activity of EFASC against resistant isolates}

The antibacterial activity assessment showed that the highest extract inhibition zone in a $500 \mathrm{mg} / \mathrm{ml}$ concentration was that generated by the growth of $C$. koseri $-\mathbf{3 1} \pm \mathbf{0 . 9 3}$ and $C$. freundii $-\mathbf{2 9} \pm \mathbf{0 . 9 3}$. Such results also revealed high (significant) correlation with EFASC concentration (62.5, 125,250 and $500 \mathrm{mg} / \mathrm{ml}$ ) against the isolates - as explained in (Table 4). Furthermore, the technique revealed that even low conc. of extract were more active than cefreaxone against these pathogens:

Table 4. Antibacterial activity of EFA SC against Citrobacter spp. isolates

\begin{tabular}{|c|c|c|}
\hline Conc. of EFASC & C. freundii & C. koseri \\
\hline $500 \mathrm{mg} / \mathrm{ml}$ & $29 \pm 0.93$ & $31 \pm 0.93$ \\
\hline $250 \mathrm{mg} / \mathrm{ml}$ & $27 \pm 1.20$ & $28 \pm 1.20$ \\
\hline $125 \mathrm{mg} / \mathrm{ml}$ & $22 \pm 0.79$ & $24 \pm 0.99$ \\
\hline $62.5 \mathrm{mg} / \mathrm{ml}$ & $20 \pm 0.75$ & $22 \pm 0.75$ \\
\hline Cefreaxone & $19 \pm 0.5$ & $18 \pm 0.48$ \\
\hline
\end{tabular}

\section{DISCUSSION}

We found that, over all, $C$. freundii was the most common infection agent recovered from the different clinical specimens. This was not in conflict with the results of [23], who found that $C$. freundii is the most common pathogen in $6.6 \%$ of all diarreatic patients, $2 \%$ of all UTI patients and $2 \%$ from wounds. In our study, the second most common pathogen was $C$. farmeri. This result is similar too, with that of [24], who noted the commonality of $6 \%$ for Citrobacter spp. isolated from UTIs. Moreover, according to [25], C. koseri was the causative agent of UTIs, while [26] isolated $C$. farmeri from UTI and wound infections.

World-wide, antimicrobial resistance is a major clinical problem in treating bacterial infection. In our work, most of the isolates can be considered multi-drug resistant. This result is in agreement with a study done locally by [6], who found C. freundii isolates were $100 \%$ resistant to cefoxitin and had varying degree of resistance to ceftazidime, aztreonam, ciprofloxacin and gentamicin. Our results were not different from the results of [27], who isolated $C$. freundii from UTIs and found that all Citrobacter isolates were resistant to cefotaxime and ceftriaxone, and can be considered as being MDR-bacteria. Moreover, [23] also observed that $C$. freundii had $100 \%$ resistance to $\beta$-lactam antibiotics. In addition, [28] observed increased prevalence of multidrug resistance in Enterobacteriaceae, making nearly all members of this family showing resistance to B-lactam and cephalosporin. This they saw even in rarely pathogenic members such as Pantoea spp. They put forward that this came about as a result of horizontal gene transfer. The work of [29] also found that C. koseri were the predominant urine pathogen and recorded high rates of resistance to cefexime, amox-cla and cephaloxin. In addition, according to [30], some Citrobacter isolates contain chromosomally mediated $\beta$-lactamases such as Cephalosporinase and Penicillinase that have led to the emergence of drug resistance and treatment failure despite initial susceptibility [30].

In our study, $17(89.4 \%)$ of the isolates were ESBL producers. The rates of resistance to cephalosporins and monobactam might be considered, therefore, as markers for the production of ESBL by these isolates. This may 
have come about by their producing the common group of class A $\beta$-lactamases, consisting of TEM, SHV and CTX-M $\beta$-lactamases that have extended hydrolytic spectrum activity to cephalosporins [31].

We hold that the proportion of ESBL-producing Enterobacteriaceae are increasing worldwide. This finding is in accordance with that of [27], who reported that $C$. freundii were ESBL-producers and that isolates possess both CTX M 1 and 2 genes. What is more, [4] revealed that $C$. freundii were ESBL-producers and hold to $100 \%$, the CTX-M gene. The prevalence of bacteria which produced more than one type of ESBL enzyme is considered most dangerous [32].

Our study shows that CTX-M $\beta$-lactamase was the most prevalent (43.75\%) among the ESBL producing isolates (Figure 3). This is in agreement with several other studies such as [33] in Najaf, who found that CTX-M $\beta$-lactamase was the most prevalent (38.7\%) among the ESBL producing G-ve isolates, followed by SHV (33.9\%); while TEM and OXA $\beta$-lactamases were the less (27.4\% for each). Of note, [34] noticed that all the Citrobacter spp. harbor bla genes, the prevalence of these genes being $b l a_{\mathrm{CTX}-\mathrm{M}}, b l a_{\mathrm{TEM}}, b l a_{\mathrm{SHV}}$ and bla ${ }_{\mathrm{AmpC}}$, respectively. Finally, [35] revealed that $C$. koseri isolated from UTI patients were multi-drug resistant and harbored the TEM, SHV-ESBL genes. According to [36], however, SHV $\beta$-lactamases enzymes are mainly found in G-ve bacteria.

Our TLC analysis revealed the presence of brown spots in the same locale as the EFA omega 3 standard. Both of these gave $\mathrm{Rf}=0.37$. Such results are in accordance with [19] who found that the $\mathrm{Rf}$ value $=0.36$, and with [37], who explained that EFA - omega 3, when using hexan solvent, gave an $\mathrm{Rf}$ value of 0.34 .

In the second part of our experiment, fourteen isolates that revealed $\beta$-lactam antibiotic resistance were chosen so as to examine the impact of EFASC extracts. The result of this part of the experiment illustrated the susceptibility of the resistant isolates to EFASC even in low concentrations. Indeed, generally, 12 of the $14(85.7 \%)$ resistant bacteria showed growth inhibition despite different concentrations of EFASC. The results of [19] also show that EFASC seed oil extracts possess good antibacterial activity against nosocomial infection bacteria. Furthermore, our results are in agreement with those of [21], who indicated the strong effect of EFASC against E.coli and S.aureus at varied levels. Moreover, our results are compatible with the study of [38], who found that the antibacterial action of fatty acids is usually attributed as being a property of the long-chain unsaturated fatty acids, including oleic acid, linoleic acid and linolenic acid. Indeed, [39] noted that polyunsaturated essential fatty acids play a role in inhibiting the growth of bacteria that contain a penicillinase plasmid. In this regard, [40] explained that fatty acids modulate the fluid permeability of cell membranes - which can greatly affect membrane properties.

\section{CONCLUSIONS}

EFASC can be considered useful alternative therapeutic agents in treating a wide range of antibiotic-resistant bacteria because they are safe, highly active and dependable, with less harmful side effect than antibiotics. The last cost more, have sometimes dangerous and often uncomfortable side effects, and to which, most bacteria now show resistance.

\section{REFERENCES}

1. Janda, J.M. et al. Biochemical identification of citrobacteria in the clinical laboratory. J. Clini Microbi. 32(8): 1850-1854, 1994.

2. Nada, T. et al.: Small outbreak of third generation cephem-resistant Citrobacter freundii infection on a surgical ward. JPN. J. Infectious Diseases. 57:181-2,2004.

3. Shih, C.C. et al.: Bacteremia due to Citrobacter species: significance of primary intraabdominal infection. Clinical Infectious Diseases. 23(3): 543-549,1991.

4. Al-Hasnawi, A. A.: Comparison of biochemical tests, Api system, Vitek 2 system and PCR of the enteropathogenic bacteria isolated from children with persistent diarrhea. And the occurrence of virulence factors and antibiotic resistance in the isolates. Master Thesis. Faculty of Science, University of Kufa 2014.

5. Al-Hissnawy, D.; AL-Thahab, A.A.; Al-Jubori,S.A.: Evaluation of Citrobacter freundii isolated in Najaf governorate as an enterotoxin producer. Medical J. Babylon. 9(1): 1-5, 2012.

6. Tuwaij, N.S.: Molecular Study of Quinolone Resistance in Klebsiella pneumoniae and Citrobacter freundii Isolates. Al-Kufa University J. for Biology 8(3): 300-312, 2016.

7. Harvey, R.A. and Champe, D.C.: Lippincott's Illustrated Reviews: Pharmacology $5^{\text {th }}$ ed., Lippincott Williams and Wilkins, USA. 382-385, 2012.

8. Fuad, M.M.et al.: In Vitro Antibacterial Activity of Common Antibiotics and Herb Extracts to Clinical Isolates of Escherichia coli Collected from UTI Patient. Int. J. of Rese in Pharmacel and Biomedi Sciences. 3(2): 987-992, 2012.

9. Wang, H. et al.: Comparison of phytochemical profiles and health benefits in fiber and oil flaxseeds (Linum usitatissimum L.). Food Chem. Jan 1;214: 227-33, 2017.

10. Desbois,A.P. and Lawlor K.C.: Antibacterial Activity of Long-Chain Polyunsaturated Fatty Acids against Propionibacterium acnes and Staphylococcus aureus. Mar. Drugs 11: 4544-4557, 2013.

11. Shin,S.Y., Bajpai, H.R. and Kang,S.C.: Antibacterial activity of ecosapantaenoic acid (EPA) against foodborne and food spoilage microorganism.LWT-Food Sci. Tech.,40: 1515-1519, 2007.

12. Singhal, M. and Paul, A.(2011): Antibacterial evaluation of synthesized methyl semicarbazone derivatives. IJPSR. 2(10): 2602-2604.

13. MacFaddin, J.E.: Individual Biochemical Tests For Identification of Medical Bacteria. $3^{\text {th }}$ ed. Lippincott Williams Wilkins, London: 57-424, 2000

14. CLSI. Performance Standards for Antimicrobial Susceptibility Testing: Twenty-Fourth Informational Supplement M02-A11, M 0-A11, and M11-A8. Wayne, PA, USA.2014.

15. Batchoun, R.G.; Swedan, S.F. and Shurman, A.M.: Extended spectrum $\beta$-lactamases among Gram-negative bacterial isolates from clinical specimens in three major hospitals in Northern Jordan. J. Micro. Res. Article, 2009,ID 513874.

16. Hassan, M.et al.: Detection of extended spectrum beta-lactamasesproducing isolates and effect of AmpC overlapping. Infect. Dev., 7(8): 618-629, 2013.

17. Colom,K et al.: Simple and reliable multiplex PCR assay for detection of blaTEM, blaSHV and blaOXA-1 genes in Enterobacteriaceae. FEMS Microbiology Letters, 223: 147-151, 2013.

18. Svärd, L. (2007): Evaluation of phenotypic and genotypic extended spectrum beta-lactamase detection method. M.Sc. Thesis. School of Biological Sciences, Dublin Institute of Technology, Uppsala University, Germany.

19. AL-Ramahi, A.A.; Darweesh, M. A., Ahmad A. M.: The Antibacterial of Essential Fatty Acid Semicarbazide Extracted from Flaxseed Oil Against Some Nosocomial Infection Bacteria in Iraq. IJCPR; 8(1) January-February: 31-39, 2017.

20. Harborne, J. B. (1984): Phytochemical Methods.; A Guide to Modern Techniques of Plant Analysis, 2nd ed. Chapman and Hall, London. 
21. Borhade, S.: Synthesis, Characterisation and Antimicrobial Activity of Essential Fatty Acid of Semicarbazide. Int.J. of Chem.Scie.and Applic. 5(2): 46-55, 2014.

22. Egharevba, H. O. et al.: Phytochemical analysis and antimicrobial activity of Punica granatum L. (fruit and leaves). New York Scie. J. 3 (12): 91-98, 2010.

23. AL-Muslemawi, TH. A. (2007): Study of some biochemical, biologica and pathological properties of lipopolysaccharide extracted from Citrobacter freundii. Ph.D.Thesis. Baghdad univ.

24. Salih, M.K., Alrabadi, N.I., Thalij, K.M. and Hussien, A.S.: Isolation of Pathogenic Gram-Negative Bacteria from Urinary Tract Infected Patients. Open Journal of Medical Microbiology, 6, 59-65, 2016.

25. Stewart, Z. E. ; Shaker M.; Baxter, J. D.: Inflammation and Infection Urinary Tract Infection Caused by Citrobacter koseri in a Patient With Spina Bifida, an Ileal Conduit and Renal Caluli Progressing to Peri-nephric Abscess and Empyema. Urology Case Reports 11: 22-24, 2017.

26. Warren, J. et al.: Out break of nosocomial infection due to extended - spectrum beta- lactamase producing strain of enteric group 137, a new member of the family Enterobacteriaceae closely related to citrobacter farmer and C. amalonatica. J. Clin. Microbio. 38(11): 3946-52, 2000.

27. Hassan, M.M. et al.: Molecular characterization of antibiotic resistance genes in pathogenic bacteria isolated from Patients in Taif Hospitals, KSA. AJPCT. 2(8): 939-951, 2014.

28. AbdAlhussen, L.S. and Darweesh, M.F.: Prevelance and antibiotic susceptibility patterns of Pantoea spp. isolated form clinical and environmental sources in Iraq. I.J.of ChemTech Research, 9 (08): 430-437, 2016

29. Metri, B.C.; Jyothi, V.X. and Peerapur B. V.: Antibiotic resistance in Citrobacter spp. isolated from urinary tract infection. Urol Ann. Oct-Dec; 5(4): 312-315,2013.

30. Sami, H.et al.: Citrobacter as a uropathogen, its prevalence and antibiotics susceptibility pattern. 4 (1): 23-26,2017.
31. Bush, K.; Jacoby, G. and Medeiros A.: A functional classification scheme for $\beta$-lactamases and its correlation with molecular structure. Anti. Agents Chemo.,39: 1211-1233, 1995.

32. Erlandsson, M. (2007). Surveillance of antibiotic consumption and antibiotic resistance in Swedish intensive care units. Linkoping University Medical Dissertations No. 1019 Sweden.

33. Al-Muhannak, F. H. N. (2010): Spread of Some Extended Spectrum Beta-Lactamases in Clinical Isolates of Gram Negative Bacilli in Najaf. M.Sc. Thesis. College of Medicine, University of Kufa.

34. Shahid, M.: Citrobacter spp. Simultaneously harboring bla- CTX-M, blaTEM, blaSHV, bla-ampC, and insertion sequences IS26 and orf513: an evolutionary phenomenon of recent concern for antibiotic resistance. J Clin. Microbi. 48(5): 1833-1838,2010.

35. Perilli, M. et al.: Novel TEM-type extended-spectrum beta-lactamase, TEM-134, in a Citrobacter koseri clinical isolate. Antimicrob. Agents Chemother. 49: 1564-1566, 2005.

36. Huang, Z.M. et al.: Study on molecular epidemiology of SHV type beta-lactamase encoding genes of multiple-drug - resistant Acinetobacter baumannii. Zhonghua Liu. Xing Bing Xue Za Zhi.,25: 425-427,2004.

37. Pandya, P., Harisha, C.R., Shandla,V.J. and Chandola, H. M.: Pharmoacogostical and Photochemical evaluation Atasi (Linum ustatissimmum L.). Indian Journal of Tradition Knowledge. 12(4): 688-692, 2013

38. Seidel, V., Taylor, P.W.: In vitro activity of extracts and constituents of Pelagonium against rapidly growing mycobacteria. Int. J. Antimicrob. Agents,23: 613-619, 2004.

39. Mogensen, T.H.: Pathogen recognition and inflammatory Signaling in innate immune. Defenses. Clin.Micro. Rev. 22(2): 240-273,2009.

40. Ibarguren, M.; Lopez, D. and Escriba, P.: The effect of natural and synthetic fatty acids on membrane structure, microdomain organization, cellular functions and human health. Biochi.et Bioph. Acta. 1838: 1518-1528, 2014 